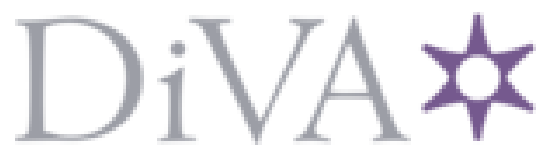

http://www.diva-portal.org

\title{
Postprint
}

This is the accepted version of a paper published in Journal of Eastern African Studies. This paper has been peer-reviewed but does not include the final publisher proof-corrections or journal pagination.

Citation for the original published paper (version of record):

Opitz, C., Fjelde, H., Höglund, K. (2013)

Including Peace: The Influence of Electoral Management Bodies on Electoral Violence.

Journal of Eastern African Studies, 7(4): 713-731

http://dx.doi.org/10.1080/17531055.2013.841024

Access to the published version may require subscription.

N.B. When citing this work, cite the original published paper.

Permanent link to this version:

http://urn.kb.se/resolve?urn=urn:nbn:se:uu:diva-212885 


\title{
Including Peace:
}

\section{The Influence of Electoral Management Bodies on Electoral Violence ${ }^{1}$}

\author{
Christian Opitz, Hanne Fjelde \& Kristine Höglund
}

\begin{abstract}
What accounts for the difference between peaceful and violent elections in semiauthoritarian countries? This article analyzes the influence of Electoral Management Bodies (EMBs) on the likelihood of widespread violence triggered by opposition protest during election times. We argue that by establishing inclusive and collaborative relationships through which political actors can jointly negotiate important electoral issues, EMBs influence the incentive structure of the major stakeholders in favor of non-violent strategies. The relationship is explored by comparing elections in Malawi (2004), Ethiopia (2005), and Zanzibar (2005). The analysis supports the idea that inclusive EMBs, rather than legal independence, are critical to guarantee the influence of the opposition in order to address both their interests and mistrust of electoral politics.
\end{abstract}

KEYWORDS: elections, conflict, electoral violence, electoral management bodies

\footnotetext{
1 This is an author's accepted manuscript of an article published in Journal of Eastern African Studies published online 15 October 2013. To cite, please use the following information: Christian Opitz, Hanne Fjelde \& Kristine Höglund (2013). Including Peace: The Influence of Electoral Management Bodies on Electoral Violence, Journal of Eastern African Studies, 7:4, 713-731, DOI: $10.1080 / 17531055.2013 .841024$
} 


\section{Introduction}

Electoral violence poses a daunting paradox. In theory, democratic electoral processes offer genuinely peaceful means to distribute political power within a society. ${ }^{1}$ Indeed, in some of the Sub-Saharan Africa countries that transitioned from authoritarianism in the 1990s, electoral cycles have served to embed a more democratic system capable of peacefully regulating political competition. In other countries the electoral contest is associated with widespread violence. One of the common manifestations of electoral violence - seen in Kenya in 2007-2008 and Ivory Coast in 2000 - is opposition protest against electoral results, followed by violent government repression and generalized violence. ${ }^{2}$ What explains this variation?

We focus on the role of Electoral Management Bodies (EMBs), i.e. the formal units principally responsible for the organization and conduct of elections, in mitigating the risk of electoral violence in Africa's electoral regimes. ${ }^{3}$ Specifically, we analyze the role of electoral governance in defusing post-election violence following contested electoral results. The relatively small literature on EMBs emphasizes the importance of independent EMBs in bestowing legitimacy and credibility on the electoral processes, particularly in "third wave democracies". 4 The argument holds that in semiauthoritarian regimes, where democratic institutions coexist with illiberal practices giving incumbents a significant advantage vis-à-vis their opponents, legally autonomous EMBs help insulate electoral governance from government manipulation and play a potentially important role in leveling the playing field. ${ }^{5}$

In this study, we move beyond a legal understanding of EMBs and focus on how governance is exercised through these institutions. We argue that in semi-authoritarian 
regimes, where opposition parties are likely to be distrustful and fear government manipulation of the electoral process, partisan oversight and multi-party deliberations might dissipate suspicion and create mutual confidence in the electoral process. Inclusive and collaborative relationships, allowing political parties to jointly negotiate electoral issues, facilitate consensus-building and become informal structures of mutual restraint that shapes the incentive structure of major stakeholders in favor of non-violent strategies. If the opposition is granted meaningful influence over electoral governance, they are less likely to challenge the conduct and outcome of the elections in an extralegal manner, halting an escalatory dynamic wherein governments often deploy repressive counter-violence. This argument regarding the role of EMBs is explored through a comparison of elections in Malawi (2004), Ethiopia (2005), and Zanzibar (2005).

Our analysis supports the above argument and furthers an understanding of the relationship between EMBs and electoral violence. In Ethiopia, the conduct of the electoral commission contributed to a severe political crisis in which the opposition challenged the voting result through extra-legal means following the lack of influence over the electoral process. In Malawi, EMBs contributed to a relative calm by generating legitimacy for the electoral process by including ruling and opposition parties, especially at the local level. Zanzibar, finally, experienced only limited violence and there are reasons to believe that the opposition's decision to refrain from extralegal challenges was influenced by a realization that EMBs may provide a structure through which frustration could be channeled without risking an escalation of violence. In these cases, it was not the legal status of the electoral commission that seemed to influence the occurrence of electoral violence. While we acknowledge the importance 
of contextual factors, our analysis points to the potential significance of electoral governance for preventing destructive electoral disputes.

Our study contributes to the literature on the determinants of electoral violence. While case studies of high-profile elections are plentiful, and general conceptual discussions exist, there is a lack of systematic comparative studies on the topic. ${ }^{6}$ By shedding light on the link between EMBs and electoral violence we also contribute to the discussion on how electoral governance can be strengthened to ensure stability during transitional periods.

\section{The Virtues of Inclusive EMBs}

Competitive elections constitute a key pillar of democratic governance. ${ }^{7}$ Free and fair elections thus confer legitimacy and "a right to rule" to the regime in power, and help sustain the underlying process of democratization. ${ }^{8}$ Despite their appeal, the empirical record of electoral politics in bestowing legitimacy and accountability onto Africa's electoral regimes is highly mixed. Because nominally democratic institutions such as competitive elections often coexist alongside illiberal and even authoritarian traits, the electoral playing field is often tilted in favor of the incumbent. In competitive authoritarian regimes, the fairness of electoral competition may be compromised for example by restraints placed on oppositions parties ability to campaign, flawed voter registration, ballot stuffing, and the misuse of state resources in governing party's campaign. ${ }^{9}$ 
Flawed electoral processes have led opposition parties across Africa to dispute electoral outcomes. The elections in Kenya in 2007, Ivory Coast in 2010, and Djibouti in 2013 are a few examples, where the announcement of electoral results has triggered extralegal protest by opposition parties over alleged electoral manipulation. Oftentimes protest has been met with government repression and widespread deployment of security forces. Such state-sponsored violence is sometimes a continuation of intimidation and coercion in the pre-election phase as part of the incumbency's "menu of manipulation" to influence electoral outcomes. Yet, the trajectory of post-election violence outlined above carry a particularly high risk of escalating to high levels of generalized violence. ${ }^{10}$

EMBs potentially have a central role to play in mediating this predicament, as these bodies can create the foundation for free and competitive elections. ${ }^{11}$ Electoral governance is vital to secure the procedural certainty that is necessary to uphold democracy as a system of "organized uncertainty". ${ }^{12}$ The opposition, in particular, places a high premium on transparent and credible electoral governance because of their political and organizational disadvantage vis-à-vis the incumbent. ${ }^{13}$ Distrust in the government to run fair elections often coexist with the lack of institutional capacity to conduct electoral administration in a satisfying way, particularly in an environment of general resource scarcity. Technical problems may often converge into political ones, and reactions often break out "at the intersection between political suspicion and technical incapacity". ${ }^{14}$ In this context, electoral governance becomes critical in shaping the perceptions and behavior of the parties and their supports to sustain the process of democratic transition. 
Scholarly discussions about EMBs in administrating elections that support peaceful democratic transition has primarily focused on the legal provisions surrounding EMBs composition and their relationship with executive and legislative branches. The dominant approach has been to emphasize independence and non-partisanship as the most important factors for guaranteeing the impartial imperative of electoral governance. ${ }^{15}$ An EMB must be an independent agency that is formally autonomous in composition and mode of operation - from the influence of political forces, particularly the government. The more insulated political pressure is from the commission (for example where appointment and oversight of EMBs is vested with the judiciary and the bodies are composed by civil-servants), the greater the chances to conduct credible elections and ensure a level of legitimacy that prevent electoral disputes. ${ }^{16}$

The focus on formal independence may, however, offer a too narrow view of the influence of EMBs capacity for facilitating elections that are deemed credible by all parties. ${ }^{17}$ Furthermore, this factor cannot account for the variation over time in the occurrence of electoral violence. Fairly clean elections administered by seemingly independent EMBs have produced results that were heavily contested in some countries, while deeply flawed polling has been accepted in others. ${ }^{18}$ The peacefulness of the electoral process arguably depends not only on the autonomy and independence characterizing the process, but on how disputes are managed and solved between the government, opposition, and the EMB.

In democracies, issues about the independence of EMBs tend to revolve around the question of how to isolate the EMB from the influence of all political parties. The main 
goal is to de-politicize the electoral governance. ${ }^{19}$ In semi-authoritarian countries, however, the overriding concern is rather to free the electoral process from the influence of the ruling government. To advance support for the electoral process, actors might opt for a pluralistic body of electoral administration, including both representatives from the opposition as veto players alongside government agents, or alternatively party nominees. ${ }^{20}$ According to this alternative view, partisan participation in the functioning of the EMB could facilitate inter-group trust and contribute to the legitimacy of the electoral process. In polities where democratic experience is weak, party representation in EMBs might advance electoral integrity through electoral inclusiveness. ${ }^{21}$

Particularly, in countries where informal institutions, such as patron-client relationships, exercise a significant influence on politics it could be misleading to solely focus on the formal independence of the EMB. In this context, the opposition is likely to have little trust in the EMBs, but rather confide in people with whom they have personal relations. ${ }^{22}$ To this end, EMBs can be fora where involved actors can negotiate electoral rules and solutions that everyone can accept and adhere to. Agencies of electoral governance characterized as independent and non-partisan, may not necessarily be able to secure trust among the political elites, since informal influence and manipulation of institutions are ubiquitous in countries where formal institutions are weak and personal relationship exercise a strong influence on politics. ${ }^{23}$

Therefore, especially the opposition is likely to be interested in an inclusive functioning of the EMB, creating structures of mutual restraints, where the ruling party is forced to engage in collaborative decision-making. From their point of view, these structures constrain incumbency attempts to manipulate the electoral outcome. An electoral 
process deemed more transparent and legitimate in the eyes of the opposition parties should in turn decrease their incentives to resort to extra-legal means to contest the electoral outcome. ${ }^{24}$ Indeed, inclusive structures might help dissipate suspicion that otherwise leads technical problems and lack of capacity to degenerate into violence. From the point of view of the incumbent, inclusive EMBs might represent an opportunity to deflect opposition challenges into the institutional realm. An inclusive EMB co-opts the opposition parties into supporting the electoral process. As a result, we are less likely to see the scenario in which the opposition challenges electoral results through extra-legal means. Their buy-in to the process itself makes it more likely that the opposition will also stay within the institutional realm to settle disputes relating to electoral governance. The result, we argue, is a lower likelihood of a scenario where electoral disgruntlement is pursued on the streets with a high risk of violent government clampdowns and an escalatory dynamic. Based on this reasoning, the more inclusive the functioning of an EMB is, the less likely is the occurrence of this particular form of post-election violence in semi-authoritarian countries.

Importantly, this notion of inclusion goes beyond the de jure composition of the EMB to also include variations in how electoral governance is exercised through these institutions. The inclusiveness of the EMB denotes the extent to which all the major stakeholders are involved in important issues of electoral governance. It thus not merely refers to the representation of the major parties in a partisan EMB, but requires the active engagement with issues of electoral governance through co-operative working relationships between relevant stakeholders. Inclusion might for example be granted through the establishment of functioning multi-party liaison committees (MPLCs) or similar consultative bodies that might serve as channels of consultation and cooperation 
between the parties and those formally tasked with the conduct of elections. ${ }^{25}$

\section{Probing the Relationship}

This study presents a comparison of elections in three countries in East Africa. We focus on the third elections after the formal introduction of multi-party politics in Malawi (2004), Ethiopia (2005), and Zanzibar/Tanzania (2005). ${ }^{26}$ The three elections display a considerable across-case variance in the patterns of electoral violence. Whereas Ethiopia experienced widespread violence and coercive intimidation in the post-election period, Malawi and Zanzibar experienced only isolated events of violence. This assessment of the level of electoral violence in the three elections is shared by Straus and Taylor in their coding of electoral violence in Sub-Saharan Africa between 1990 and $2008 .^{27}$

The cases share several characteristics which make them interesting to compare. In particular, after the end of the Cold War all three countries experienced a similar transition from single-party rule to a formal introduction of a multi-party system. However, they are still heavily permeated by patron-client relationships and have a centralized system, both of which significantly raise the electoral stakes for obtaining political positions. Moreover, the elections we focus on were all of a high-stake nature, featuring electoral malpractice and allegations of incumbent manipulation of electoral results, which heightened the risk for violence. In addition, the three countries share the same electoral system of First-Past-The-Post, usually associated with higher conflict potential in unstable settings. ${ }^{28}$ 
Admittedly, the three cases differ on what may be considered as key aspects. Ethiopia experienced armed conflicts which may cause a generally higher likelihood of a resort to violence. Zanzibar has suffered from a rich history of election-related violence. However, after the 2000 election constitutional amendments were agreed upon which provided for substantial changes in the electoral management. Malawi has generally been less violent, but electoral malpractice has resulted in attempts to reform electoral governance institutions. In relation to each of the case analyses, we will explore the extent to which the history of violence and electoral path dependence may have influenced the absence or presence of electoral violence.

The cases are analyzed with the use of structured focused comparison and a set of questions derived from our key theoretical concepts are raised to each of the cases to guide the empirical analysis. We define electoral violence as "physical violence and coercive intimidation directly tied to an impeding electoral contest or an announced electoral result." 29 In this study we are interested in electoral violence which occurs in the post-election period (although it may have its roots in any aspect before or after the polling). Our argument primarily highlights the ability of EMBs to prevent opposition forces from contesting electoral disputes through extra-legal means, and thus prevent more generalized post-election violence. We define inclusiveness of EMBs as regular structures of relationships between the EMB and major stakeholders based on collaborative problem-solving, which yield substantive authority over all aspects of electoral governance. We hypothesize that the systematic inclusion of the opposition will address the opposition's mistrust in electoral politics. 
In order to gauge the presence of electoral violence and its linkages to the functioning of the EMBs we explore the following questions in each case:

- Was there significant violence in the post-election period triggered by the opposition's use of extra-legal measures, such as protests or demonstrations against electoral results?

- Did the EMBs provide institutional structures for the inclusion of the opposition, for instance, via party liaison committees at the national or local level?

- Was the decision-making approach within these structures based on bargaining and problem-solving without the dominance of a particular actor?

- How did the (non-)existence of inclusive electoral governance structures shape the opposition's perception of the election?

- Are there any rival explanations to the violent or peaceful outcome of the election?

\section{Malawi 2004: EMB Inclusiveness at the Local Level}

In 1994, Malawi held its first multi-party election after three decades of one-party rule. The first presidential election was won by Bakili Muluzi, who retained a second term five years later. During the first years of the post-authoritarian period, the major political groups variously opposed and aligned with each other in order to capitalize on the exclusive system of patronage around the president. This generated a fluid party system, characterized by fragmented parties and short-term political coalitions. Flexibility at the top of politics has served to override regional cleavages that have caused minor election-related violence, but without threatening the political order. ${ }^{30}$ 
The violence which has occurred around elections, for instance in 1999, has been of an isolated and opportunistic nature. ${ }^{31}$ In this context, it must be noticed that Malawi has been spared from large-scale political violence or civil war, which is extraordinary given the many factors normally inducing conflict present in the country.

In advance of the 2004 election, the Malawi Electoral Commission (MEC) operated within a clear legal framework, but its independence was de facto limited. According to the law, the President was to appoint, "in consultation with the leaders of the political parties represented in the National Assembly" (Electoral Commission Act §4), the members of the MEC. This meant that the Commission comprised members who represented the interests of the different parliamentary groups. The Malawian constitution stipulated further that the MEC "shall exercise its powers, functions and duties [...] independent of any direction or inference by other authority or any person" (§76.1). The electoral quality, however, declined consistently after the introduction of multi-party politics in 1994. In particular, the 1999 elections were considerably flawed and displayed an institutional incapability to guarantee key aspects of electoral management. ${ }^{32}$

The negative development concerning electoral quality in Malawi was partly rooted in the weak authority of the MEC, further undermined by informal influence of the government. ${ }^{33}$ The incumbent regime subverted the commission's constitutional autonomy by constantly withholding government grants. Moreover, due to its party composition, the MEC suffered from partisan voting and dissent. By 2004 it served as a gateway for governmental influence because the changing coalitions guaranteed the ruling party a continuous majority in the MEC. ${ }^{34}$ This vulnerability to manipulation 
increasingly infringed on the ability of the Commission to conduct elections that were considered legitimate by all stakeholders.

The 2004 election entailed the most competitive presidential race since the first multiparty election in 1994. The election had been preceded by a period in which president Muluzi's attempt to change the constitution to allow him a third term in office was balked by the opposition and disappointed elements within the ruling party. As a result, it was Muluzi's hand-picked successor Bingu wa Mutharika who competed against two promising opposition candidates. ${ }^{35}$ Thus, it was an election with considerable stakes both for the government and the opposition. The pre-polling period was characterized by major shortcomings concerning the voter registration process, bias in the state media for the ruling party, and the use of advantageous government resources by the incumbent. ${ }^{36}$ However, the atmosphere was calm and only minor incidents reported in the run-up to the election and on polling day.

The declaration of the election result caused dismay among the opposition and created tensions which threatened to escalate. In the legislative vote, the opposition gained a majority of seats in the parliamentary. However, Mutharika, the candidate of the ruling party, was declared the presidential winner and immediately inaugurated. The opposition rejected the official figures, claiming that his victory had been rigged by the MEC and petitioned the High Court demanding the annulment of the result. ${ }^{37}$ Furthermore, opposition supporters engaged in sporadic looting and vandalizing in the Southern region, which was countered by a strong response of the police using tear-gas and live bullets. As a result of these riots, seven people died and about 100 were arrested. ${ }^{38}$ National as well international observers stated, however, that the general 
level of electoral violence was low with only a few incidents. ${ }^{39}$ The opposition ultimately did not challenge the electoral outcome by a wide-spread use of extra-legal means.

What was the role of the EMBs in contributing to low levels of violence in 2004? The conduct and structures of the EMBs significantly affected the legitimacy of Malawi's 2004 election, in three different ways. First, the overall independence of the MEC was questioned. As outlined above, the ignorance of legal stipulations has been the modus operandi for electoral governance in Malawi, including the MEC. This incompetence resulted in a prevailing distrust among the opposition against the Commission. ${ }^{40}$ Moreover, international observers criticized the MEC for a "disappointing" performance which "did not meet the expectations of stakeholders" particularly referring to a flawed voter registration and biased media coverage. ${ }^{41}$ The credibility of the MEC was further compromised by the delay in announcing the results, which fueled suspicions that the Commission was manipulating the outcome in favor of the government.

Second, national structures introduced by the MEC in the run-up to the election, intended to be a broad-based conflict management mechanism, failed. ${ }^{42}$ The National Elections Consultative Forum (NECOF) was established in 2002, and included all major political parties. By bringing together the different stakeholders the Commission hoped that it would create better relationships between itself and the contestants. It was meant as a discussion forum about the responsibilities and initiatives of the MEC and served to enforce a Code of Conduct. However, the functioning of NECOF was obstructed by conflictive politics at the national level, and the Forum only met on four 
occasions in the pre-electoral period. One reason was the limited influence of the parties on the electoral process through this forum. The MEC openly conceded the limitations in its authority ${ }^{43}$ Notably, it could not deal with the opposition concerns regarding voter registration and biased media coverage. Furthermore, it was also the apparent lack of commitment and goodwill of its participants that led to the breakdown of the NECOF. ${ }^{44}$ The political groups were only represented by lower representatives whose decisions were subsequently not obeyed by the senior leaderships. Thus, the integrative structures of NECOF could not function effectively and served more as a venue for inter- and intra-party conflicts.

Third, structures at the district level were more effective in creating inclusive electoral governance. The MEC had facilitated the establishment of Multi-party Liaison Committees (MPLCs) in the local assemblies. The MPLCs were composed of party representatives, local authorities, security forces, and NGOs, with the joint task of resolving electoral disputes, monitoring the Code of Conduct as well as investigating potential violations. Despite the violent incidents following the election results, the MPLCs and their integrative activities were praised by the participants, valuing the opportunity to come together across party divides without the influence from leaders at the national level. ${ }^{45}$ This was also stressed by the international observers, stating that these structures "proved to be a useful form for settling election-related disputes at the local level" ${ }^{46}$ and were "influential in reducing intimidation and conflict". ${ }^{47}$ For instance, disputes concerning intra-party conflicts, misuse of the police, demarcation, and allegations of electoral fraud were solved by the MPLCs in Kasungu, Nkhata Bay, Ntchisi, Zomba, Ntcheu, Chiradzula and Blantyre. ${ }^{48}$ 
The experience of the MPLC in preventing violence from escalating in Malawi's contested election suggests several important conclusions concerning EMBs. First, inclusive EMBs at the local level appear to be especially important in countries like Malawi where political parties function with a negligible participation of local supporters in decision-making processes. ${ }^{49}$ The frequent divisions at the national level without consulting the grass-root structures exemplify this dominance of party elites. Yet, in the MPLCs, the local politicians engaged, in contrast to their party leaders, in compromising. Collaborative practices enhanced not only the trust between the contestants but also the popular confidence in electoral politics. ${ }^{50}$

Second, the MPLC did not work in isolation from other institutions important for electoral and conflict management. In particular, the courts, that had become increasingly independent and trusted, played a larger role in all aspects of the electoral process in the 2004 election. ${ }^{51}$ Moreover, the Malawian state and its (electoral) institutions are heavily dependent on external funding, which may have influenced the politicians' decision to refrain from engaging in disastrous violence in anticipation of the severe consequences by the donor community. ${ }^{52}$ Combined with a history of no major political violence these factors also contributed to the prevention of large-scale electoral violence.

Third, the integrative structures at the national level and at the local level had been put in place due to the increasing numbers of electoral disputes and were meant to address those types of conflicts. This indicates a relationship not only between EMBs and their influence on violence, but also on how the institutional set-up is influenced by anticipated conflict. 
To conclude, inclusive EMBs in Malawi can to some extent claim to have contributed to preventing violence from escalating during Malawi's contested 2004 election. In the light of high-stake elections and deeply patrimonial politics around the president, the MPLCs provided local stakeholders with an opportunity to solve issues in a collaborative manner. Especially the opposition was thereby granted influence on electoral governance, which may have reduced their incentives to resort to violent means to challenge the poorly administrated electoral process. However, the MEC was not capable of guaranteeing procedural certainty nor could it sustain positive interactions between the party leaderships. If anything, the Commission seems to be a part of a halting democratic transition, rather than part of the democratic solution, thereby laying a fertile ground for future conflict..$^{53}$

\section{Ethiopia 2005: Post-electoral Partiality}

Ethiopia's transition to multi-party politics began in 1991, when the Marxist-Leninist military junta led by Mengistu Haile Mariam was defeated by the Ethiopian People's Revolutionary Democratic Front (EPRDF). A Transitional Government and interim constitution was established. This period was characterized by high levels of interethnic violence, which resulted in the withdrawal of important political groups from the EPRDF government and their boycott of the constituent assembly. ${ }^{54}$ In the first competitive general election under the new constitution in 1995, the EPRDF won an overwhelming parliamentary majority due to the refusal of the major opposition parties to participate. Some opposition groups competed in the 2000 election but were unable to effectively challenge the dominant position of the ruling party. The dominance of the EFRDP was partly due to state-sponsored violence and intimidation which occurred 
during the electoral periods. ${ }^{55}$ Ethiopia, thus, has a history of civil war, ethnically-based conflict, and political violence during election periods.

The National Election Board of Ethiopia (NEBE) has been a bone of contention between the contestants since the introduction of the multi-party system. ${ }^{56}$ The Board consists of seven members appointed by the parliament upon the recommendation of the Prime Minister "on account of their allegiance to the Constitution, non-partisanship of any political organization and professional competence" (Election Law §4). The Constitution further prescribes that the "Board shall be an impartial and autonomous agency and shall be responsible for ensuring that all Federal and State elections shall be free and fair" $(\S 102.1)$. Irregularities during the first two elections, however, questioned the autonomy of the NEBE. In particular the appointment procedure, which effectively empowered the EPRDF to decide the composition of the Board, was perceived by the opposition as an infringement on NEBE's ability to conduct legitimate elections which in combination with violent oppression, resulted in their boycott of the first two elections. ${ }^{57}$

As a response to international pressure, Prime Minster Meles Zenawi negotiated with the main opposition parties to discuss improvements of the electoral governance in the run-up to the general election in May 2005. ${ }^{58}$ The government agreed to amend the electoral law, meeting some of the demands, including the presence of international observers and a more balanced coverage by the state-run media. The opposition parties United Ethiopian Democratic Forces (UEDF) and the Coalition for Unity and Democracy (CUD), subsequently decided to participate in the election although more structural demands concerning the reform of the NEBE were rejected. 
The pre-polling period and the day of election were remarkable open and only a few irregularities were reported. For the first time, the Ethiopians seemed to have a genuine choice between different parties and candidates. The international observers saw the "increased political space in the pre-election period was one of the most significant achievements". ${ }^{59}$ However, tensions grew when preliminary results indicated that the opposition was likely to obtain a surprisingly large number of seats in the parliament. When confronted with an unexpected challenge to its dominance, the EPRDF used its power over the NEBE to manipulate the results.

The situation deteriorated further when the Board finally released the voting results, which suggested that the ruling party had unexpectedly regained its clear parliamentary majority. The opposition criticized these figures and unrest began to spread in June. Ignoring a demonstration ban put in place by Prime Minister Zenawi, the opposition supporters protested against the outcome. The security forces responded by firing live bullets. In the ensuing violence more than 40 people were killed, hundreds were injured and thousands of alleged participants arrested. Furthermore, the government did not create a safe environment for a credible review process of the election. In the postpolling period, police and security forces violated human rights, through physical assaults, verbal threats and unfounded arrests of opposition supporters. ${ }^{60}$ This violence purposefully hampered the ability of the opposition to present its cases and compromised the integrity of the review process. When NEBE eventually announced the final results in September, the UEDF and CUD immediately rejected the official figures and boycotted re-elections in those constituencies in which the review process had annulled the previous outcome. Subsequently, internationally-facilitated 
negotiations between the opposing camps failed and public demonstrations re-erupted in November. The security forces again used excessive force against the protesters and more than 40 people were killed, hundreds wounded, and thousands arrested. ${ }^{61}$

To what extent and how did the EMBs contribute to the high levels of electoral violence in the post-election phase? Several points emerge from an analysis of the conduct and composition of the electoral institutions. First, during the pre-polling phase, the Board played a significant role by establishing the Joint Consultative Committees (JCCs) as platforms for meetings among the major stakeholders. The JCCs comprised NEBE personnel and party representatives and convened periodically to mediate in campaignrelated disputes. The meetings "served an important and much-needed function in a highly polarized political environment, facilitating constructive dialogue between the parties". ${ }^{62}$ The JCCs, thus, offered an inclusive structure for conflict prevention in a context where the electoral environment remained tense with instances of intimidation and harassment. ${ }^{63}$

Second, in spite of these achievements, the opposition parties remained skeptical of the conduct of the NEBE, suspecting that the EPRDF was only seeking international approval without risking its actual power. ${ }^{64}$ During the vote tallying and tabulation, numerous problems were reported and the international observers concluded that the electoral process was seriously flawed. The NEBE "demonstrated an inability to administer effectively key parts of the election" ${ }^{65}$ The chaos of the count also resulted in a breakdown of the previously functioning structures of the JCCs. UEDF and CUD demanded greater transparency, while the EPRDF used its dominance over the Board to limit electoral losses. In this situation of intense political influence, the NEBE was 
not able to uphold inclusive channels of communication between the adversaries and lost not only its already limited trust among the opposition, but also authority over electoral management.

Third, the Ethiopian case illustrates how EMBs can work in two directions in relation to electoral violence. Violence may be a response to exclusive and biased EMBs, but can also be used to obstruct the functioning of electoral structures. Due to the flawed electoral process, the ensuing violence, and immense international pressure, the EPRDF and the opposition parties signed an agreement that expressed their commitment to resolve the lingering issues peacefully by initiating a comprehensive review mechanism. ${ }^{66}$ It provided for the establishment of two bodies under the supervision of the NEBE, the Complaints Review Board (CRB) and the Complaints Investigation Panels (CIPs). The CRB was given main responsibility to decide whether each complaint had sufficient evidence to qualify as irregularity and whether this had significantly affected the final result. In order to prevent any partisan interference, the NEBE declared that the CRB would comprise representatives of the parties as well as electoral officials. However, the performance of the CRB was questionable as it rejected the majority of the opposition complaints on the grounds that the evidence was not sufficient, while most of the requests by the ruling party were accepted. ${ }^{67}$ Once approved by the $\mathrm{CRB}$, the complaints were brought in front of the CIP. The Panel consisted of three members, one from the complaining party, a representative of the previously declared winner, and one NEBE secretariat official. ${ }^{68}$ Since a majority vote would suffice to reach a final decision, it was almost inevitably the task of the NEBE representative to guarantee the impartiality of the CIP. However, the Board's "refusal to hear evidence, lack of clear explanations of reasoning, and the quick dismissal of 
arguments all added to the perception that the NEBE was operating under the political influence of the ruling party". ${ }^{69}$ This was worsened by the general trend of EPRFD and NEBE members outvoting the opposition parties. Moreover, during the review process, violence was used by the security forces against UEDF and CUD, which effectively hindered the opposition to present its case. ${ }^{70}$ Thus, violence delegitimized the review process and became a source of new contention.

To conclude, the main cause of the electoral violence in the 2005 election relates to a political system where the degree of oppression complies with the extent to which the ruling party is challenged. In this election the opposition proved to be surprisingly strong, and the government used excessive violence in the aftermath of the voting. ${ }^{71}$ However, the influence of the EMBs contributes to an explanation of the dynamics at play. Initially, the NEBE promoted inclusive relationships with both government and opposition which contributed to a relatively peaceful campaign period. The commission's function, however, changed completely when EPRDF effectively took control over the electoral governance, which triggered protest by the UEDF and CUD, and subsequent violent responses by the government. The demonstrations were caused not only by the deficiencies in the electoral process, but were also informed by the experience of previous elections. It confirmed to the opposition that they were allowed to compete, but not to win. The disappointment with the regime caused outrage particularly among the engaged, urban Ethiopians, which also explain why the confrontation between protesters and security forces primarily took place in urban areas. $^{72}$ In a context where the incumbent party does not allow for the possibility of electoral loss, collaborative problem-solving will lose its meaning, even if inclusive structures are in place. 


\section{Zanzibar 2005: Inclusive Rules without a Consensual Game}

Zanzibar is part of Tanzania, but enjoys a semi-autonomous political status including its own president, legislature and judiciary. In 1992, one-party rule was abolished in Tanzania and multi-party politics was introduced. However, unlike the political stability of the mainland, the transition in Zanzibar has been highly fragile and violent. The major tensions have been between the main political parties Chama cha Mapinduzi (CCM, Kiswahili for Party of the Revolution) and the Civic United Front (CUF). CCM has held power both nationally and in Zanzibar. The conflict displays both geographic (Unguja versus Pemba) and ethnic (Arab versus African) cleavages, has escalated during the election periods, but reaches back to colonial times. ${ }^{73}$ The political instability peaked after heavy protests by the opposition against the 2000 presidential victory of CCM's Amani Abeid Karume. The electoral process was heavily criticized by international observers, particularly referring to highly flawed voter rolls and nontransparent tallying. The subsequent clashes threatened the general stability on the island, leading to at least 30 deaths and several hundred displaced people. ${ }^{74}$

The turmoil of 2000 was the final setback for the Zanzibar Electoral Commission (ZEC). Observers saw the ZEC as a major institutional reason for the re-occurring electoral violence, repeatedly displaying technical incompetency to administer voting procedures. In addition, the Commission's personnel and financial dependence on the ruling CCM further substantiated the view among the CUF opposition of an illegitimate government vehicle. In the aftermath of the crisis, reconciliation talks between CCM and CUF resulted in the Muafaka Accord in October 2001. The agreement tried to alleviate the poor reputation of the ZEC, which has already been constitutionally, but 
not empirically stipulated to be autonomous from the government. According to the Accord, the President was to appoint not only a chairperson, and two non-aligned members, but also two commissioners nominated by the government and two recommended by the leading opposition in the parliament. The authority of the ZEC was further strengthened by its mandate to appoint its own officers and compile a permanent register of voters, less vulnerable to manipulation. ${ }^{75}$ An additional mechanism to address inter-party distrust was the establishment of the Joint Presidential Supervisory Commission (JPSC) with representation from both CCM and CUF, which was to oversee implementation of the Muafaka Accord. ${ }^{76}$

The 2005 election was thus held against the backdrop of the 2000 violence and reforms to address deficiencies in electoral governance. However, the implementation of the Muafaka Accord had been partial. ${ }^{77}$ Both the CCM and CUF fielded candidates in the presidential race and there were concerns that $\mathrm{CCM}$ would again retain power through electoral fraud and repression of the opposition. Admittedly, there was low-level violence throughout the campaigning period, manifested in "sporadic incidents of violence and intimidation". ${ }^{78}$ However, it was widely acknowledged by observers that the voting process was "markedly less violent than was the case in previous elections" ${ }^{79}$ When the final results saw the close re-election of CCM's Karume, CUF did not accept the electoral outcome, claiming that ZEC had rigged the tallying in favor of the incumbent. The opposition announced that it would not recognize the new CCM government, but that they would take up its seats in parliament. The CUF supporters took to the streets to demonstrate against the results, but it was reported that the heavy presence of police and security forces prevented the eruption of violence. In addition, 
the CUF leadership helped to alleviate tensions with calls to its members to renounce violence. $^{80}$

To what extent did the EMBs contribute to diffusing tensions and prevent large-scale violence? First, reports suggest that the performance of the ZEC in the election "minimized sources of conflict between EMBs and election stakeholders" $"$, although the electoral process still suffered from various inadequacies, including a nontransparent tallying procedure. The general judgment among the international and domestic observers was that of by and large free and fair elections. They were unanimous in highlighting the "significant improvement" of electoral governance by the ZEC in comparison with the previous voting cycles. ${ }^{82}$

Second, to understand the role of the ZEC in the 2005 election, it is necessary to distinguish between the institutional design of the ZEC and the way governance was exercised within this structure. On the one hand, the modified composition of the ZEC did not seem to have a decisive influence on its lack of independence as perceived by the opposition. Although the CUF could nominate two own commissioners, mere representation did not guarantee its influence over the electoral process. In fact, the incumbent president could still fill the majority of positions in the Commission. The opposition's confidence in the legitimacy of the ZEC was weak even after the Muafaka reforms. Demonstrated by decisions divided along partisan lines, the inclusion of party agents on the ZEC resulted in "politicization rather than independence and impartiality". ${ }^{83}$ Rather, what enhanced the legitimacy of the ZEC was its move toward more inclusive relationships with the political parties in the constituencies. In the runup to the election, the Commission established various mechanisms for dialogue 
between CCM and CUF, including the Joint Presidential Supervisory Commission and the Committee of Secretary Generals. With the help of these inclusive structures, "in every stage of the election process ZEC held consultative meetings with the parties to agree ... upon the rules, regulations and conduct governing each stage" ${ }^{84}$ Although there were reported incidents of violence caused by supporters of both parties, they were commonly characterized as "sporadic" and even actively defused by the respective party leadership encouraged by the ZEC. ${ }^{85}$

Third, to attribute the relatively calm post-election period solely to inclusive EMBs would be to overestimate their role in the context of the 2005 election. Prior to the announcement of the electoral results, CUF had threatened to unleash "people power" if the election continued to be characterized by irregularities. However, CUF admitted that previous attempts to boycott or protest elections had not yielded expected results and the risk of disproportionate response by the security forces was high. Moreover, the CUF may have feared that the international community would not support their protest, given their backing of CCM. In addition, there are reports that the inclusive structures did not function satisfactory and that the parties had lost faith in the reform process even before the election started. ${ }^{86}$ Nonetheless, there are claims that CUF may have had hopes that differences between the parties could be solved with the reactivation of JPSC, given for instance statements by former Tanzanian president (belonging to the $\mathrm{CCM}$ ) that the parties should try to use such channels to reconcile. ${ }^{87}$ Thus, it is reasonable to assume that CUF weighed potential risks of violence versus a peaceful solution to the disputes when taking the decision not to protest the vote in a way that would have provoked the CCM and the security forces to use violence. 
In conclusion, the EMB in Zanzibar was situated in a very difficult context, in which the main political parties of CCM and CUF could not agree on a common electoral framework because of historical and political antagonisms. In 2005, the ZEC was praised for an improved performance by all independent observers. Importantly, it facilitated the establishment of inclusive structures with and between the two groups through which CUF at least hoped that disputes could be resolved. Combined with an enhanced preparation of the security forces, these efforts contributed to an electoral process which was less violent compared to previous polling periods. The refusal of the opposition to accept the results, however, points to prolonged political instability rooted in causes beyond mere electoral governance. Repeated electoral violence must be seen in the context of a hard-fought competition for the status and identity of the island, to which voting mechanisms provide only a limited solution. ${ }^{88}$ For this reason, EMBs have only limited influence in supporting political stability in Zanzibar.

\section{EMBs and Violence Prevention}

An analysis of the three elections in Malawi, Ethiopia, and Zanzibar sheds light on the relationship between the inclusiveness of EMBs and post-electoral violence triggered by the oppositions' dissatisfaction with the electoral process. The election results were challenged in all three cases by the opposition, but only in the Ethiopian election did this challenge escalate into widespread violence due to retaliatory actions by the security forces.

To what extent and in what ways did the EMBs contribute to the presence or absence of violence in these elections? Our analysis suggests that EMBs in Malawi and, to a lesser extent, Zanzibar were able to establish collaborative relationships with the major 
political parties, and prevented the domination of one actor which helped to mitigate a high predisposition to violence. In Ethiopia, on the other hand, widespread violence after the polling can partly be attributed to the failure of the EMB to provide inclusive electoral governance in the face of manipulation of the election results by the incumbent and subsequent challenges by the opposition. Critically, it was not the legal independence of the EMBs, all electoral commission were formally autonomous from the ruling regime, but the extent to which they were able to accommodate the interest and mistrust by the oppositions which mattered.

The case studies underline that EMBs do not work in a societal vacuum, but must be analyzed as "embedded institutions" that interact with their environment. ${ }^{89}$ This is exemplified by the difference between the EMBs formal structures and the actual modus operandi. For instance, the analysis highlights that the influence of EMBs are highly contingent on the prevailing power structures among the political parties. In Ethiopia the dominant elites easily re-modeled the electoral framework to serve their own interests. These efforts also show that electoral institutions may influence the incumbents' political choices, as considerable resources are invested to manipulate EMBs when ruling regimes are at the risk of losing international legitimacy. The incentives for the opposition parties were accordingly geared towards confrontation, as they saw no other means to challenge the outcome.

Inclusive EMBs can thus only yield benefits if they are granted genuine authority to perform their main responsibilities. Local MPLCs in Malawi shaped the interaction between the parties by imposing constraints on violent actions and providing opportunities for conciliatory initiatives. The regulations were established in a 
collaborative manner and allowed the districts to overcome the overly power-driven discourse of the center. Even in Zanzibar with its conflict-ridden past, the integrative structures offered by the EMB - or at least anticipation that they may provide an alternative to an electoral challenge that would have the potential to escalate into widespread violence - contributed to the relatively low levels of violence.

EMBs are also embedded institutions in the sense that they are only one part of an explanation of the causes of electoral violence. Decisions of the contestants which may result in generalized violence are influenced by other factors as well. One important factor relates to general institutional strength and the capability and authority of specific institutions related to the election. In a context of weak and politicized institutions, the ruling party can make the playing field uneven in ways that an inclusive EMB cannot overcome. For instance, in Ethiopia the police and security forces were misused by the incumbent and used excessive force against the opposition protesters. Similar institutions and processes may also be more important than the EMB in shaping whether or not opposition parties will accept the results. In Malawi, the judicial bodies complemented inclusive EMBs in building confidence in the electoral process. International pressure may also play a role. For instance, in Zanzibar the opposition anticipated no external pressure on the incumbent, which may have influenced their decision to refrain from challenging the electoral results by street protest.

A final feature of EMBs as embedded institutions points to the influence of electoral violence on the reform of electoral governance. The analysis highlights reverse causality in the sense that violence has triggered attempts to reshape the electoral framework in all three countries. Attempts to reform the EMBs were influenced by 
previous trajectories of violence and conflict, which determines the level of trust between the main contestants and their willingness to concede political power. As outlined in the case analyses, Ethiopia had been marked by both civil war and electoral violence, Zanzibar had a history of violent electoral competition, and Malawi had experienced some, but more limited, electoral violence. These differences are recognized as important in determining the extent to which reform is possible and the way in which political power is exercised.

\section{Conclusion}

To understand the causes of electoral violence, it is important to scrutinize the functioning of the institutions governing the electoral processes. Although contextual factors need to be considered, including the general role of elections as peaceful distributors of political power within a society and its previous history of conflict, the study suggests that inclusive EMBs can play decisive roles in the reduction of electoral violence by preventing the opposition from taking to the streets and challenge the incumbent, which at times may create escalatory dynamics. Moving beyond the façade of formal institutions, the findings have implications for the field of electoral assistance. In a highly politicized context, it may caution against the over-emphasis on legal structures instead of focusing on how electoral management is actually exercised within these institutions. 90 "Good" electoral governance in terms of violence prevention cannot easily be deduced from the formal design of the EMB. Rather than solely aiming at producing conditions for granting the "free and fair" label, the international community might be best advised to find ways to support collaborative and trustbuilding relationships between the EMBs and political parties to prevent conflict. 


\section{Acknowledgements}

We gratefully acknowledge funding from the Swedish Research Council.

${ }^{1}$ Dahl, Polyarchy.

2 Electoral violence can be defined as "physical violence and coercive intimidation directly tied to an impeding electoral contest or an announced electoral result" (Straus and Taylor, "Democratization and Electoral Violence," 19). The manifestations of electoral violence are multifaceted (Höglund "Electoral Violence"). Pre-election violence might involve coercive intimidation against individual citizens or party supporters to suppress voter turnout or influence voting behavior (Bratton, "Vote buying and violence"). Electoral violence may also take the form of violent grabbing of resources when political actors use patronage to mobilize electoral support (Boone "Politically Allocated Land Rights"). It can occur in the post-election phase: as riots to protest results, or as violent government repression to overturn results (Bekoe, "Political Agreements"). Violence may also be unrelated to the electoral outcome and be a means through which intra-party cohesion is reinforced (LeBas, From Protest to Parties).

${ }^{3}$ The terms Electoral Management Body and electoral commission are used interchangeably in this study.

${ }^{4}$ Birch, "Electoral Institutions and Popular Confidence"; Reilly, "Post-Conflict Elections".

${ }^{5}$ Lòpez-Pintor, Electoral Management Bodies; Levitsky and Way, Competitive Authoritarianism, 12.

${ }^{6}$ See, for example, Rapoport and Weinberg, "Elections and Violence"; Reilly, "PostConflict Elections"; Straus and Taylor, "Democratization and Electoral Violence"; Boone, "Politically Allocated Land Rights".

${ }^{7}$ Dahl, Polyarchy; Przeworski, Democracy and the Market.

${ }^{8}$ Lindberg, "Democracy and Elections".

${ }^{9}$ Schedler, "The Menu of Manipulation"; Diamond, "Thinking about Hybrid Regimes"; Levitsky and Way, Competitive Authoritarianism.

${ }^{10}$ Straus and Taylor, "Democratization and Electoral Violence," 33.

${ }^{11}$ Hartly, et al. "Electoral Governance Matters"; Elklit and Reynolds, "The Impact of Election Administration"; Lòpez-Pintor, Electoral Management Bodies.

12 Przeworski, Democracy and the Market, 13.

${ }^{13}$ Mozaffar, "Patterns of Electoral Governance".

${ }^{14}$ Pastor, "The Role of Electoral Administration", 10.

${ }^{15}$ Schedler, "The Menu of Manipulation"; Mozaffar, "Patterns of Electoral Governance".

${ }^{16}$ Birch, "Electoral Institutions and Popular Confidence", 306; Lehoucq. "Can Parties Police Themselves?".

${ }^{17}$ Gazibo, "The Forging of Institutional Autonomy".

${ }^{18}$ Elklit and Reynolds, "Judging Elections", 204.

${ }^{19}$ Schedler, "The Menu of Manipulation," 13.

${ }^{20}$ Mozaffar and Schedler, "The Comparative Study of Electoral Governance".

${ }^{21}$ Schaffer, "Might Cleaning Up Elections"; Lòpez-Pintor, Electoral Management Bodies. 
22 Schedler, "The Menu of Manipulation", 10.

${ }^{23}$ Birch, Electoral Management Bodies; Guillermo Rosas, "Trust in Elections".

${ }^{24}$ Elklit and Reynolds, "The Impact of Election Administration"; Lyons, "Postconflict Elections".

${ }^{25}$ Moepya, "The Role of Multiparty Liaison Committees"; UNDP, Elections and Conflict Prevention.

${ }^{26}$ The analysis focuses on Zanzibar. Zanzibar is formally a part of Tanzania, but culturally distinct and enjoys far-reaching degree autonomy.

${ }^{27}$ Straus and Taylor, "Democratization and Electoral Violence", 25-26.

${ }^{28}$ Reilly, "Post-Conflict Elections"; Reilly and Reynolds, "Electoral Systems and Conflict".

${ }^{29}$ Straus and Taylor, "Democratization and Electoral Violence", 19.

${ }^{30}$ Englund, A Democracy of Chameleons.

${ }^{31}$ Kadzamira, "The Management of the Electoral Process".

${ }^{32}$ Patel, "1999 Elections in Malawi".

${ }^{33}$ Khembo, "The Anatomy of Electoral Democracy in Malawi," 63.

${ }^{34}$ Rakner and Svåsand, "Maybe Free but Not Fair”, 11.

${ }^{35}$ Hussein, "Opposition Politics in Malawi".

${ }^{36} \mathrm{AU}$, "Report of the African Union"; Commonwealth, "Report of the

Commonwealth Observer Group: Malawi"; Khembo, "The Anatomy of Electoral

Democracy in Malawi"; EU-EOM, "Republic of Malawi".

${ }^{37}$ Khembo, "The Anatomy of Electoral Democracy in Malawi".

${ }^{38}$ EU-EOM, "Republic of Malawi", 34.

${ }^{39}$ Patel, "Troublemakers and Bridge Builders", 233; Commonwealth, "Report of the

Commonwealth Observer Group; Malawi”, 48.

${ }^{40}$ Rakner and Svåsand, "Maybe Free but Not Fair", 13.

${ }^{41}$ AU, "Report of the African Union", 20; EU-EOM, "Republic of Malawi", 3.

${ }^{42}$ Rakner and Svåsand, "Maybe Free but Not Fair", 14.

${ }^{43}$ EU-EOM, "Republic of Malawi", 35.

${ }^{44}$ Rakner and Svåsand, "Maybe Free but Not Fair", 15.

${ }^{45}$ Patel, "Troublemakers and Bridge Builders", 233.

${ }^{46}$ Khembo, "Elections and Democratisation in Malawi", 64.

${ }^{47}$ EU-EOM, "Republic of Malawi", 17.

${ }^{48}$ Patel, "Troublemakers and Bridge Builders", 231-234.

${ }^{49}$ Hussein, "Opposition Politics in Malawi", 355.

${ }^{50}$ Patel, "Troublemakers and Bridge Builders", 233.

${ }^{51}$ Rakner and Svåsand, "Maybe Free but Not Fair", 10.

${ }^{52}$ Khembo, "Elections and Democratisation in Malawi", 50-61.

${ }^{53}$ Rakner and Svåsand, "Maybe Free but Not Fair", 16.

${ }^{54}$ Harbeson, "Ethiopia's Extended Transition", 148.

55 Arriola, "Ethnicity, Economic Conditions"; Smith, "Disturbance or Massacre?".

56 Tronvoll, "Ambiguous Elections", 451.

${ }^{57}$ EU-EOM, "Ethiopia", 15.

${ }^{58}$ EU-EOM, "Ethiopia", 8.

${ }^{59}$ Carter Center, "Observing the 2005 Ethiopia National Elections", 20.

${ }^{60}$ Carter Center, "Observing the 2005 Ethiopia National Elections", 31; EU-EOM, "Ethiopia", 28.

${ }^{61}$ Lyons, "Ethiopia in 2005", 2.

${ }^{62}$ Carter Center, "Observing the 2005 Ethiopia National Elections", 15.

${ }^{63}$ Carter Center, "Observing the 2005 Ethiopia National Elections", 16-17. 
${ }^{64}$ EU-EOM, "Ethiopia", 8.

${ }^{65}$ Carter Center, "Observing the 2005 Ethiopia National Elections", 39.

${ }^{66}$ Teshome, "Electoral Violence in Africa", 468.

${ }^{67}$ Carter Center, "Observing the 2005 Ethiopia National Elections", 27-28.

${ }^{68}$ EU-EOM, "Ethiopia", 28.

${ }^{69}$ Carter Center, "Observing the 2005 Ethiopia National Elections", 32.

${ }^{70}$ EU-EOM, "Ethiopia", 28.

${ }^{71}$ Clapham, "Post-war Ethiopia"; Tronvoll, "Ambiguous Elections".

${ }^{72}$ Smith, "Disturbance or Massacre?".

${ }^{73}$ Killian, "The State and Identity Politics in Zanzibar".

${ }^{74}$ Brown, "Political Tension in Zanzibar".

${ }^{75}$ EISA Election Observer Mission Report No 22, 5.

${ }^{76}$ Bekoe, "Political Agreements".

${ }^{77}$ Bekoe, "Political Agreements".

${ }^{78}$ Commonwealth, "The Report of the Commonwealth Observer Group: Zanzibar," 33.

${ }^{79}$ EISA Election Observer Mission Report No 22, 12.

${ }^{80}$ TEMCO, "Report of the Tanzania Election", 54-55.

${ }^{81}$ EISA, "Election Talk", 8.

${ }^{82}$ Commonwealth, "The Report of the Commonwealth Observer Group: Zanzibar," 52; EISA Election Observer Mission Report No 22; NDI, "International Observation Mission"; TEMCO, "Report of the Tanzania Election".

${ }^{83}$ TEMCO, "Report of the Tanzania Election", 76.

${ }^{84}$ TEMCO, "Report of the Tanzania Election", 62.

${ }^{85}$ NDI, "International Observation Mission", 23.

${ }^{86}$ Bekoe, "Political Agreements", 134-137.

${ }^{87}$ Bekoe, "Political Agreements", 137; FEWER, "Electoral Violence and Reconciliation", 5.

${ }^{88}$ Brown, "Political Tension in Zanzibar"; Karume, Dilemmas of Political Transition, 13.

${ }^{89}$ Mozaffar and Schedler, "The Comparative Study of Electoral Governance”, 13.

${ }^{90}$ Birch, Electoral Management Bodies.

\section{Bibliography}

African Union (AU). "Report of the African Union Observer Team on the Presidential and Parliamentary Elections in the Republic of Malawi held on 20th May", 2004, available at http://www.africaunion.org/Official_documents/reports/Report\%20AU\%20Observer \%20Team\%20\%20Malawi\%202004.pdf [01.04.2011]).

Arriola, Larry R. "Ethnicity, Economic Conditions, and Opposition Support: Evidence from Ethiopia's 2005 Election.” Northeast African Studies 10, no. 1 (2008): 115-144.

Bekoe, Dorina. "Postelection Political Agreements in Togo and Zanzibar". In Voting in Fear, edited by Dorina Bekoe, 15-38. Washington D.C.: USIP Press, 2012. 
Birch, Sarah. "Electoral Institutions and Popular Confidence in Electoral Processes." Electoral Studies 27, no. 2 (2008): 305-320.

Birch, Sarah. Electoral Management Bodies and the Conduct of Elections, unpublished manuscript, 2007.

Boone, Catherine. "Politically Allocated Land Rights and the Geography of Electoral Violence: The Case of Kenya in the 1990s." Comparative Political Studies 44, no. 10 (2011): 1311-1342.

Bratton, Michael. "Vote Buying and Violence in Nigerian Election Campaigns." Electoral Studies 27, (2008): 621-632.

Brown, Andrea. "Political Tension in Zanzibar: Echoes from the Revolution?" Canadian Journal of Development Studies 30, no. 3-4 (2010): 611-633.

Commonwealth. "Report of the Commonwealth Observer Group: The Elections in Zanzibar, United Republic of Tanzania 30 October 2005." 2005, available at http://www.tz.undp.org/ESP/docs/Observer_Reports/2005/Commonwealth_Observati on_Re port_2005.pdf [06.04.2011].

Commonwealth. "Report of the Commonwealth Observer Group: Malawi Parliamentary and Presidential Election 20 May 2004." 2004, available at http://www.thecommonwealth.org/shared_asp_files/uploadedfiles/\%7BE2DF93B391EA-4B3F-BCC8199EAB105B75\%7D_malawi\%20final\%20report\%20_electronic\%20version.pdf

Carter Center, "Observing the 2005 Ethiopia National Elections: Carter Center Final Report." 2009, available at http://www.cartercenter.org/resources/pdfs/news/peace_publications/election_reports/ Ethiop ia-2005-Finalrpt.pdf [13.04.2011].

Clapham, Christopher. "Post-war Ethiopia: The Trajectories of Crisis." Review of African Political Economy 120, no. 36 (2009): 181-192.

Dahl, Robert. Polyarch: Participation and Opposition. New Haven: Yale University Press, 1971.

Diamond, Larry. "Thinking about Hybrid Regimes." Journal of Democracy 13 no. 2(2002): 21-35.

EISA Election Observer Mission Report No 22: Zanzibar Presidential, House of Representatives and Local Government Elections 30 October 2005. 2006, available at http://www.eisa.org.za/PDF/zanomr05.pdf [06.04.2011]).

EISA. "Election Talk 27" (18.10.2005). 2005, available at http://www.eisa.org.za/PDF/et27.pdf [06.04.2011]. 
Elklit, Jørgen and Andrew Reynolds. "The Impact of Election Administration on the Legitimacy of Emerging Democracies." Commonwealth and Comparative Politics 40, no. 2 (2002): 86-119.

Elklit, Jørgen and Andrew Reynolds. "Judging Elections and Election Management Quality by Process.” Representation 41, no. 3 (2005): 189-207.

Englund, Harri, ed. A Democracy of Chameleons: Politics and Culture in the New Malawi. Uppsala: Nordic Africa Institute, 2002.

European Union Election Observation Mission (EU-EOM). "Republic of Malawi: Presidential and Parliamentary Elections 20 May 2004." 2004, available at http://www.eueom.eu/files/dmfile/EUEOMMalawi2004FinalReport.pdf [01.04.2011].

European Union Election Observation Mission (EU-EOM). "Ethiopia: Legislative Elections 2005." 2005, available at http://eeas.europa.eu/human_rights/election_observation/ethiopia/final_report_en.pdf [13.04.2011].

FEWER, "Electoral Violence and Reconciliation Zanzibar", Nairobi: Forum on Early Warning and Early Response - Africa, 2005.

Gazibo, Mamoudou. "The Forging of Institutional Autonomy." Canadian Journal of Political Science 39, no. 3 (2006): 611-633.

Harbeson, John. "Ethiopia's Extended Transition." Journal of Democracy 16, no. 4 (2005): 144-158.

Hartly, Jonathan, Jennifer McCoy and Thomas Mustillo. "Electoral Governance Matters: Explaining the Quality of Elections in Contemporary Latin America." Comparative Political Studies 41, no. 1 (2008): 73-98.

Höglund, Kristine. "Electoral Violence in Conflict-Ridden Societies." Terrorism and Political Violence 21, no. 3 (2009), 412-427.

Hussein, Mustafa Kennedy. "Opposition Politics in Malawi." South African Journal of International Affairs 16, no. 3 (2009): 347-369.

Kadzamira, Zimani. "The Management of the Electoral Process." In Malawi's Second Democratic Elections, edited by Martin Ott et al., 52-66. Blantyre: Claim, 2000.

Karume, Shumbana. Dilemmas of Political Transition: Towards Institutionalisation of Multiparty Democracy in Tanzania. Johannesburg: EISA, 2006.

Khembo, Nixon. "The Anatomy of Electoral Democracy in Malawi." In Outside the Ballot Box, edited by Jeanette Minnie, 63-84. Windhoek: MISA, 2004.

Khembo, Nixon. Elections and Democratisation in Malawi: An Uncertain Process. Johannesburg: EISA, 2005. 
Killian, Bernadeta. "The State and Identity Politics in Zanzibar." African Identities 6, no. 2 (2008): 99-125.

LeBas, Adrienne. From Protest to Parties: Party-Building and Democratization in Africa. Oxford: Oxford University Press, 2011.

Lehoucq, Frederic. "Can Parties Police Themselves? Electoral Governance and Democratization.” International Political Science Review 23, no.1 (2002): 29-46.

Levitsky, Steven and Lucan Way. Competitive Authoritarianism. Cambridge: Cambridge University Press, 2010.

Lindberg, Staffan I. Democracy and Elections in Africa. Baltimore: The John Hopkins University Press, 2006.

Lòpez-Pintor, Rafael. Electoral Management Bodies as Institutions of Governance. New York: United Nations Development Programme.

Lyons, Terrence. "Post-conflict Elections and the Process of Demilitarizing Politics: The Role of Electoral Administration.” Democratization 11, no. 3 (2004): 36-62.

Lyons, Terrence. "Ethiopia in 2005: The Beginning of a Transition?" Center for Strategic and International Studies: African Notes No. 25, 2006, available at http://csis.org/files/media/csis/pubs/anotes_0601.pdf [13.04.2011]).

Moepya, Mosotho. "The Role of Multiparty Liaison Committees in Preventing and Managing Conflict in South Africa." In When Elephants Fight, edited by Khabele Matlosa et al., 143-153. Johannesburg: EISA, 2010.

Mozaffar, Shaheen. "Patterns of Electoral Governance in Africa's Emerging Democracies.” International Political Science Review 23, no. 1 (2002): 85-101.

Mozaffar, Shaheen and Andreas Schedler. "The Comparative Study of Electoral Governance." International Political Science Review 23, no. 1 (2002): 5-27.

National Democratic Institute (NDI). "International Observation Mission: 2005 Zanzibar Elections October 30, 2005." 2005, available at http://www.tz.undp.org/ESP/docs/Observer_Reports/2005/NDI_\%20Zanzibar_Obser vation_Report_2005.pdf [06.04.2011].

Patel, Nandini. "1999 Elections in Malawi: Challenges and Reforms." In Malawi's SecondDemocratic Elections, edited by Martin Ott et al., 158-185. Blantyre: Claim, 2000.

Patel, Nandini. "Troublemakers and Bridge Builders." In The Power of the Vote. Malawi's 2004 Parliamentary and Presidential Elections, edited by Martin Ott et al., 217-242. Zomba: Kachere, 2005.

Pastor, Robert A. "The Role of Electoral Administration in Democratic Transitions." Democratization 6, no. 4 (1999): 8-9. 
Przeworski, Adam. Democracy and the Market. Cambridge: Cambridge University Press, 1991.

Reilly, Benjamin. "Post-Conflict Elections: Constraints and Dangers." International Peacekeeping 9, no. 2 (2002): 118-139.

Rakner, Lise, and Lars Svåsand. "Maybe Free but Not Fair: Electoral Administration in Malawi 1994-2004.” Working Paper No 5. Bergen: CMI, 2005.

Rapoport, David C., and Leonard Weinberg. "Elections and Violence." Terrorism and Political Violence 12, no. 3-4 (2000): 15-50.

Reilly, Benjamin and Andrew Reynolds. "Electoral Systems and Conflict in Divided Societies." In International Conflict Resolution after the Cold War, eds. Paul C. Stern and Daniel Druckman, 420-482. Washington: National Academy Press, 2000.

Rosas, Guillermo. "Trust in Elections and the Institutional Design of Electoral Authorities: Evidence from Latin America." Electoral Studies 29, no. 1 (2010): 74-90.

Schaffer, Frederic. "Might Cleaning Up Elections Keep People Away from the Polls?" International Political Science Review 23, no.1 (2002): 69-84.

Schedler, Andreas. "The Menu of Manipulation." Journal of Democracy, 13, no. 2 (2002): 36-50.

Smith, Lahra. "Disturbance or Massacre? Consequences of Electoral Violence in Ethiopia." In Voting in Fear, edited by Dorina Bekoe, 181-208. Washington D.C.: USIP Press, 2012.

Straus, Scott, and Charles Taylor. "Democratization and Electoral Violence in SubSaharan Africa, 1990-2008." In Voting in Fear, edited by Dorina Bekoe, 15-38. Washington D.C.: USIP Press, 2012.

Tanzania Election Monitoring Committee (TEMCO). "Report of the Tanzania Election Monitoring Committee: The 2005 General Elections in Zanzibar." 2006, available at http://www.tz.undp.org/ESP/docs/Observer_Reports/2005/TEMCO_Report_Zanzibar 2005. pdf [06.04.2011].

Teshome, Wondwosen. "Electoral Violence in Africa: Experience from Ethiopia." International Journal of Human and Social Sciences 4, no. 6 (2009): 463-488.

Tronvoll, Kjetil. "Ambiguous Elections: The Influence of Non-electoral Politics in Ethiopian Democratization." Journal of Modern African Studies 47, no. 3 (2009): 449474.

UNDP. Elections and Conflict Prevention. New York: United Nations Development Programme, 2009. 